\title{
Mechanical properties of mullite reinforced ceramics composite produced from kaolin and corn starch
} of Ceramics and Polymer Engineering as a material engineer, where she actually continues her study as PhD student under supervision of Prof. L. A. Gömze.

EMESE KUROVICS - Institute of Ceramics and Polymer Engineering, University of Miskolc, Hungary - fememese@uni-miskolc.hu

ALEKSEY S. KULKOV - Institute of Strength Physics and Materials Science SB RAS, National Research Tomsk State University

JAMAL-ELDIN F. M. IBRAHIM - Institute of Ceramics and Polymer Engineering, University of Miskolc, Hungary - jamalfadoul@gmail.com

A. D. KASHIN - Institute of Strength Physics and Materials Science SB RAS, Tomsk, 634055 Russia • kash@ispms.ru

PÉTER PALA - Refratechnik Hungaria Ltd, Hungary

VERONIKA NAGY - Institute of Ceramics and Polymer Engineering, University of Miskolc, Hungary

SERGEI N. KULKOV - Institute of Strength Physics and Materials Science SB RAS, National Research Tomsk State University - kulkov@ms.tsc.ru

LÁszLó A. GÖMZE - Institute of Ceramics and Polymer Engineering, University of Miskolc, Hungary, IGREX Engineering Service Ltd · femgomze@uni-miskolc.hu

Érkezett: 2021. 06. 03. - Received: 03. 06. 2021. - https://doi.org/10.14382/epitoanyag-jsbcm.2021.22

\begin{abstract}
In this research, the authors have prepared mullite-containing ceramics by mixing Sedlecky $\mathrm{ml}$ kaolin, Nabalox 315 alumina and corn starch as a bio-origin additive. Pellets were prepared from the mixtures using an uniaxial compression process. The pressed samples were pre-sintered at $1250{ }^{\circ} \mathrm{C}$ using oxidation and reduction atmospheres and then sintered at a temperature above $1400{ }^{\circ} \mathrm{C}$ in nitrogen gas. In this way, the typical carbothermal reduction and nitridation processes of clay minerals were performed, reinforced mullite ceramics were prepared and their main mechanical properties were investigated. Based on the obtained results, sintering in nitrogen gas resulted in a more wear-resistant surface layer.

Keywords: kaolinite, mullite, nitridation, reduction, wear resistance

Kulcsszavak: kaolinit, mullit, nitridálás, redukálás, kopásállóság
\end{abstract}

\section{Introduction}

The microstructure, properties and applications of the technical ceramics are greatly influenced by the production techniques [1-3]. Starting with the raw materials, relatively inexpensive natural materials can be used to achieve costbenefit relationship, but the main drawback is the existence of some quantity of impurities in these raw materials [46]. Therefore, during the manufacturing of some high-tech ceramics and composite, high purity synthetic materials are usually used. The produced materials are normally made under special circumstances, for example, preparation of barium-titanate nanopowders through sol-gel method [79]. After the starting raw materials are selected, the next step is the formation and sintering process, then finishing the product. The main properties of the ceramics are significantly influenced by the applied temperatures and conditions of the heat treatment [10-12].

Mullite or mullite-containing ceramics can be made from different raw materials. The cost-effective way to produce the mullite phase is through thermal decomposition of kaolin or other aluminosilicates [13-15]. Mullite-based ceramics or high purity mullite ceramics can be formed by the reaction of free $\mathrm{SiO}_{2}$ and $\mathrm{Al}_{2} \mathrm{O}_{3}$ [16-19]. By controlling the reaction conditions and heat treatment, a high-tech ceramic powder or products can be prepared from kaolin clay minerals. For example,
Aleksey S. KULKOV is physicist and has got PhD scientific degree at Tomsk State University in Russian Federation. At present he is working as research fellow at Institute of Strength Physics and Materials Science of the Russian Academy of Sciences in Tomsk.

Jamal Eldin F. M. IBRAHIM is a lecturer in the University of Bahri, Khartoum, Sudan, he graduated from University of Marmara, Istanbul, Turkey, Institute of Pure and Applied Sciences, Department of Metallurgical and Materials Engineering, for the time being, he is a PhD student in the University of Miskolc, Institute of Polymer and Ceramics Engineering, under supervision of Prof. L. A. Gömze.

A. D. KASHIN is working as research assistant under supervision of Prof. Kulkov at Institute of Strength Physics and Materials Science of the Russian Academy of Sciences in Tomsk.

Péter PALA

Is a chemical engineer who finished his study at the University of Pannonia. He has been working in the ceramics industry since 2003 , at present Hungaria Ltd.

Veronika NAGY is a student of the Faculty of Materials Science and Engineering at University of Miskolc.

Sergei N. KULKOV is professor of the Tomsk State University and head of Department of Ceramics in the Institute of Strength Physics and Materials Science of the Russian Academy of Science since 1989. His research works are represented in 5 books, more than 150 articles, 18 patents and many International Symposiums and Conferences. At present he is head of department „Theory of Strength and Mechanic of Solids", member of "The American Ceramic Society” of "The APMI International" and the DYM AT Society (France).

László A. GÖMZE

is establisher and professor of the Department of Ceramics and Silicate Engineering in the University of Miskolc. Hungary. He is author or coauthor of 2 patents, 6 books and more than 300 scientific papers. Recently, he is the chair of the International Organization Board of ic-cmtp6

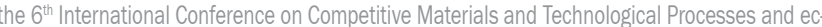
siliconf2 the $2^{\text {nd }}$ European Conference on Silicon and Silica Based Materials.

through the carbothermal reduction reaction (CRR) or the carbothermal reduction and nitridation process (CRN). Using CRR or CRN method, silicon carbide ( $\mathrm{SiC})$, silicon oxynitride $\left(\mathrm{Si}_{2} \mathrm{ON}_{2}\right)$, silicon nitride $\left(\mathrm{Si}_{3} \mathrm{~N}_{4}\right)$, SiAlONs and also aluminum nitride AlN can be prepared. In the CRN method, a mixture of various aluminosilicates, like kaolinite and active carbon or carbon black, as a carbon source is sintered at high temperature $\left(1400-1650{ }^{\circ} \mathrm{C}\right)$ using flowing nitrogen gas to create the new crystalline or amorphous phases in the material [20-27]. These new phases and their microstructure can improve the mechanical properties of the mullite-based ceramics. he is the managing director of Refratechnik 
This research aims to produce mullite-containing ceramics with a reinforced structure during the sintering of kaolinbased ceramics using nitrogen gas above $1400{ }^{\circ} \mathrm{C}$.

\section{Materials and experiments}

In this research, the authors prepared mullite-containing ceramics by mixing Sedlecky ml kaolin, Nabalox 315 alumina and corn starch as a bio-origin carbon source additive. The kaolin was the main raw material. For making the mixtures, 10 wt.\% alumina and other $0,10,20,30$ and $40 \mathrm{wt} . \%$ corn starch were added to the ceramic powders. The measured powders were milled and homogenized in a planetary ball mill, then cylindrical samples with a diameter of $25 \mathrm{~mm}$ were prepared by the uniaxial powder compression process. The pressed samples were pre-sintered at $1250{ }^{\circ} \mathrm{C}$ using oxidation (OX) and reduction (RED) atmosphere and then sintered at a temperature above $1400^{\circ} \mathrm{C}$ using nitrogen gas (OX-NIT, REDNIT).
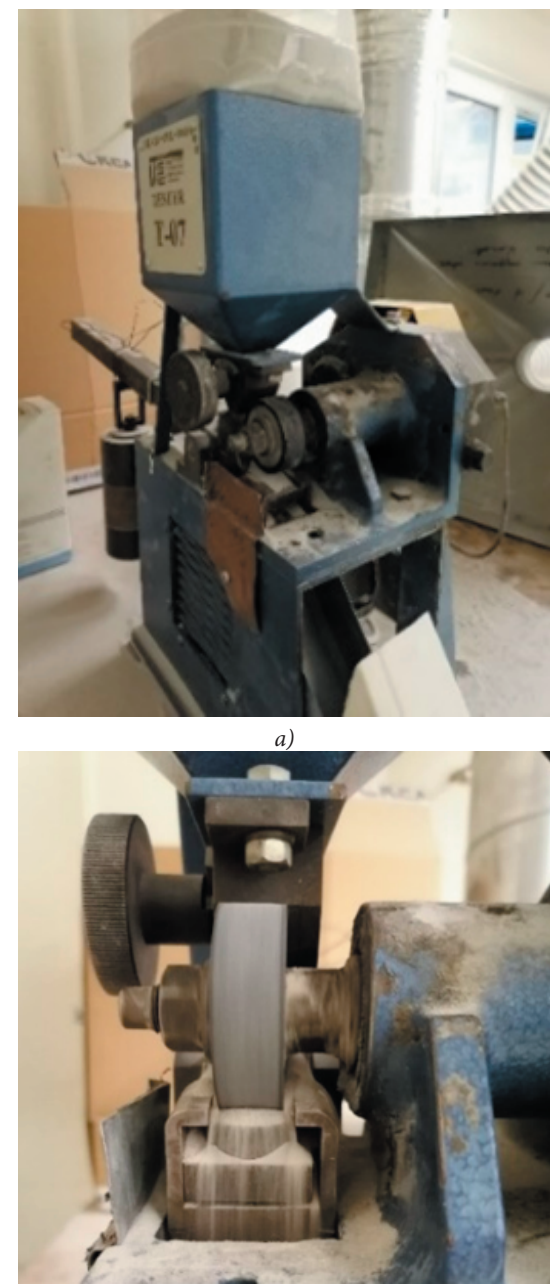

b)

Fig. 1 The abrasion wear resistance tester

1. ábra A kopásállóságméró

In this way, partly the typical carbothermal reduction and nitridation processes of clay minerals were performed and mullite-based ceramic samples were prepared with a silicon nitride and SiAlON-reinforced surface layer. To compare the properties, a part of the samples was sintered in an oxidation atmosphere at a temperature above $1400^{\circ} \mathrm{C}(14 \mathrm{OX})$. The phase compositions of the sintered ceramics were determined by an $\mathrm{X}$-ray diffractometer. Thereafter the mechanical properties of the samples such as micro-Vickers hardness (HV 0,1), abrasion resistance, compressive strength were investigated. During the abrasive wear test (Fig. 1), the sample was pressed to the rotating wheel by using a weight on the load arm. The role of the weight is to control the contact pressure. During the test, quartz sand was fed between the rotating wheel and the test sample through a feeder. After the specified times (5, 25 minutes), the sample was removed. The amount of material removed can be determined using the following formula:

$V_{\text {worn }}=\frac{m_{1}-m_{2}}{\rho_{\text {sample }}} \cdot 1000$

where $V_{\text {worn }}$ is the worn volume loss $\left[\mathrm{mm}^{3}\right], m_{1}$ is the original weight of the sample [g], $m_{2}$ is the weight after the test [g], $\rho_{\text {sample }}$ is the density of the sample $\left[\mathrm{g} / \mathrm{cm}^{3}\right][28]$.

\section{Results and discussions}

The distinctive properties of the samples have changed after the different heat treatments. Fig. 2 shows how the color of samples is changed depending on the used sintering processes.

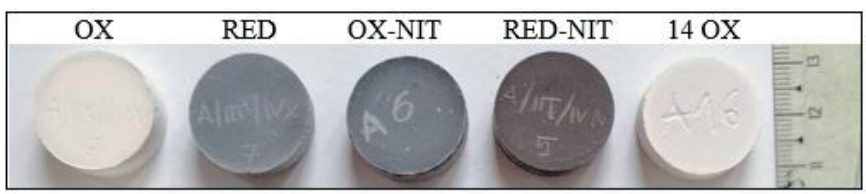

Fig. 2 The pressed samples after the pre-sintering and sintering processes 2. ábra A préselt minták az elö-szinterelési és szinterelési folyamatok után

The phase compositions of prepared samples were determined by using powder samples which were taken from the pressed samples after their heat treatment. The pre-sintered samples made without corn additive, were found to contain $43 \%$ mullite, $25 \%$ cristobalite, $1 \%$ quartz, $9 \%$ corundum and $22 \%$ X-ray amorphous based on the XRD analysis. Usually, increasing the amount of vegetable additive increase the amount of X-ray amorphous phase and decreases the amount of corundum and cristobalite phases. Using higher sintering temperature, the mullite crystal structure is changed and the amount of it increases from $43 \%$ to $70 \%$ because the $\mathrm{Al}_{2} \mathrm{O}_{3}$ from the corundum phase and the free $\mathrm{SiO}_{2}$ which was formed during the thermal decomposition of kaolin will create more secondary mullite crystals. After the phase composition analysis of the powders, no significant difference was found between the compositions of the samples made with different production methods. But when the XRD analysis were done just on the surface of the sintered samples, some new crystalline phases (Fig. 3) can be found. After the reduction pre-sintering, the test samples have hercynite and $\mathrm{SiC}$ phases while during the nitridation sintering process, nitrogen-containing phases are formed like $\mathrm{Si}_{2} \mathrm{ON}_{2}$ and $\mathrm{Si}_{3} \mathrm{~N}_{4}$. The RED and RED-NIT type samples are containing 20-44\% X-ray amorphous phases, which may hide additional nitrogen-containing nanocrystals. This is due to the fact that after the second heat treatment, the quantity of the measured X-ray amorphous phase is increased. 
The amount of cristobalite phases was decreased when the added amount of corn additive increased. Therefore, the ceramics made with corn additive can contain higher amounts of nitrogen-containing phases.

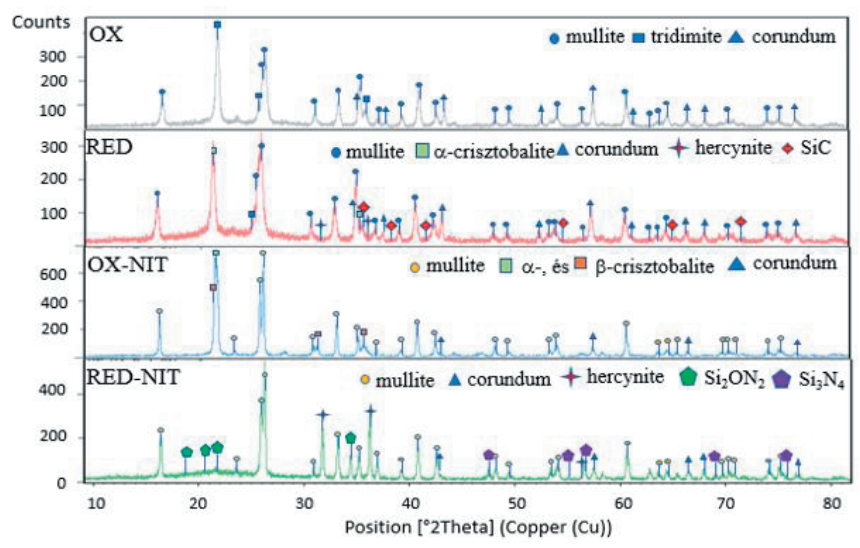

Fig. 3 The phase composition on the surface of the sintered samples made with 40 $w t . \%$ corn additive

3. ábra A 40 tömeg\% kukorica-adalékkal készitett szinterezett minták felszínének fázisösszetétele

During the research work, three characteristic mechanical properties of the samples were investigated after each sintering method. Based on the results, the mechanical properties of the ceramic samples have been carried out after the nitridation sintering. Fig. 4 shows the micro-Vickers hardness of the ceramic samples as a function of their porosity which was determined through Archimedes water absorption test. Different colors indicate the type of the sintering methods in the Figure: black - oxidation, red - reduction pre-sintering, blue - oxidation pre-sintering and nitridation sintering, green - reduction pre-sintering and nitridation sintering and finally turquoise - oxidation sintering. Generally, the micro-hardness of sintered mullite ceramics is twice the hardness of the original pre-sintered sample. Samples pre-sintered in the oxidation atmosphere have the lowest hardness. During the reduction pre-sintering, carbon-containing phases like SiC particles have formed. These $\mathrm{SiC}$ particles increase the micro hardness of the ceramic samples. The micro hardness value of the samples sintered at $1450^{\circ} \mathrm{C}(14 \mathrm{OX})$ is lower than that obtained after the nitridation sintering.

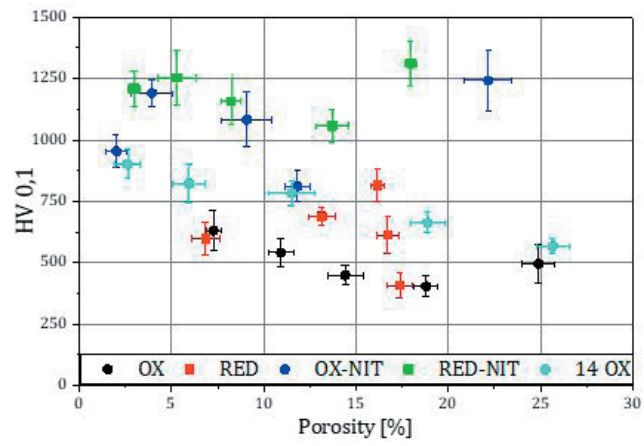

Fig. 4 The micro-Vickers hardness as function of porosity of the ceramic samples 4. ábra A mikro-Vickers keménység a kerámiaminták porozitásának függvényében

Fig. 5 shows the worn material volume after different abrasion time ( 5 and 25 minutes) as function of the porosity of the sintered samples. As the value of porosity increases, the volume of material worn per unit time increases. Especially in the case of reduction pre-sintering, the wear of ceramic samples increases dramatically. However, there is a significant improvement, thanks to the nitridation sintering. With a longer wear time, the same amount of wear can be measured for example, in the case of oxidation pre-sintering, the volume of material worn during 5 minutes of wear is the same as in the case of nitridation sintering after 25 minutes. In the case of reduction pre-sintering and nitridation sintering, the difference is even greater due to the high wear of the pre-sintered samples. As a result of nitridation sintering, the authors were able to produce mullite-based ceramic samples with higher wear resistance characteristics.
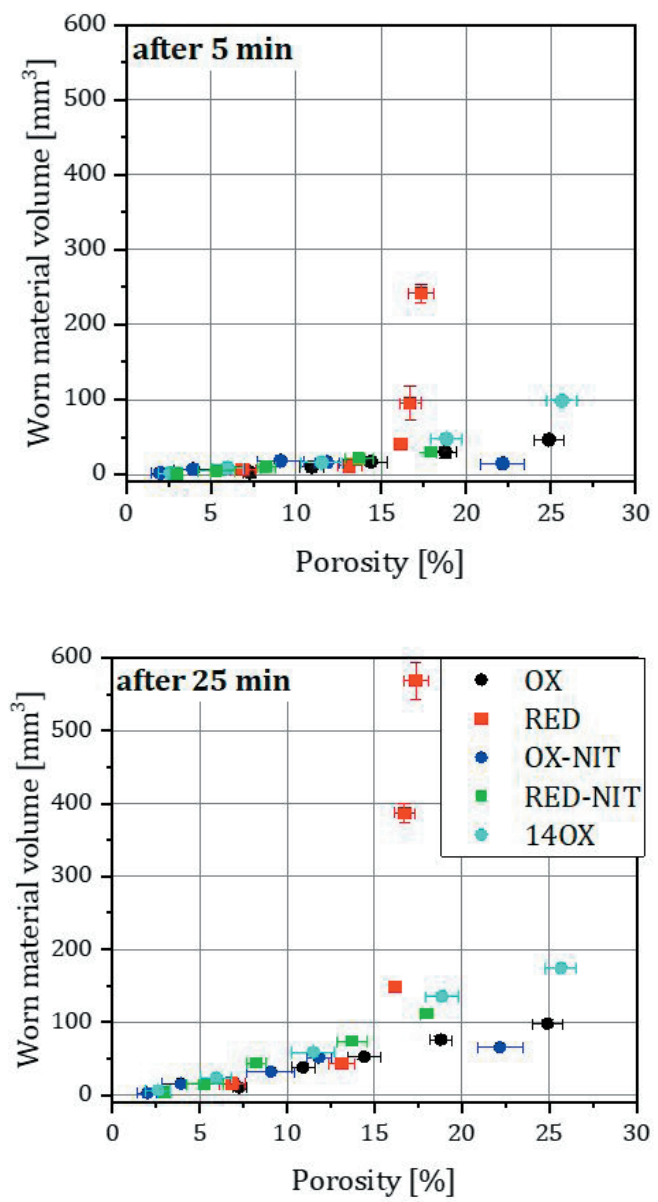

Fig. 5 The worn material volume of the ceramic samples after 5-and 25-minutes abrasion time

5. ábra A kerámiaminták kopott anyagmennyisége 5 és 25 perces koptatási idő után

Fig. 6 shows the change in compressive strength according to the change in porosity. An increase in porosity (less dense ceramic sample) has a negative effect on the mechanical strength. The compressive strength values of the samples prepared by the oxidation pre-sintering method are almost independent of the amount of corn additive. In comparison, the reduction pre-sintering significantly increases the compressive strength of the prepared ceramic samples, but with increasing the porosity of samples, their strength will decrease. For the specimens made without corn, the average strength of the 
ceramics increased from $63 \mathrm{MPa}(\mathrm{OX})$ to $215 \mathrm{MPa}$ (RED). This improvement in strength is due to a new microstructure created by sintering in the reduction atmosphere. As a result of nitridation sintering, there is a further improvement in compressive strength.

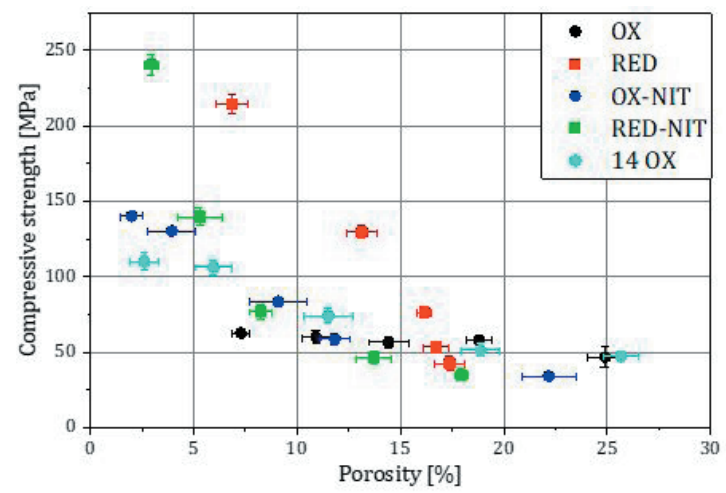

Fig. 6 The compressive strength of the ceramic samples 6. ábra A kerámiaminták nyomószilárdsága

\section{Conclusions}

Pre-sintering in the reduction atmosphere has formed carbides $(\mathrm{SiC})$ in the structure of the mullite ceramics; because of this, the ceramics have higher micro hardness (HV 0,1) and strength. During the high-temperature nitridation sintering the mullite crystal structure has changed and different nitrogen-containing phases are formed on the surface of the mullite-based ceramic samples depending on the quantity of the corn additive. The properties of the pre-sintered ceramic specimens have significantly improved after the sintering in nitrogen gas. Based on the results, the authors have successfully produced mullite ceramics with a mechanically wear resistant surface layer which are containing silicon nitride, by using high temperature $\left(>1400^{\circ} \mathrm{C}\right)$ sintering in nitrogen gas.

\section{Acknowledgements}

The described article was carried out as part of the EFOP3.6.1-16-00011 "Younger and Renewing University Innovative Knowledge City - institutional development of the University of Miskolc aiming at intelligent specialisation" project implemented in the framework of the Széchenyi 2020 program. The realization of this project is supported by the European Union, co-financed by the European Social Fund. Vickers hardness test was performed at the Institutes of Faculty of Mechanical Engineering and Informatics, University of Miskolc.

The work was performed according to the Government research assignment for ISPMS SB RAS, project FWRW-20210005.

\section{References}

[1] Otitoju, T.A., Okoye, P.U., Chen, G., Li, Y., Okoye, M.O., Li, S. (2020) Advanced ceramic components: materials, fabrication, and applications, Journal of Industrial and Engineering Chemistry Vol. 85, pp. 34-65. https://doi.org/10.1016/j.jiec.2020.02.002

[2] Kulkov, S., Buyakova, S., Gömze, L.A. (2014) Structure and mechanical properties of $\mathrm{ZrO}_{2}$-based systems, Építőanyag - JSBCM, Vol. 66. No. 1. pp. 1-6. https://doi.org/10.14382/epitoanyag-jsbcm.2014.1
[3] Gömze, L.A., Liszátzné Helvei, Á., Simonné Odler, A., Szabó, M. (2001) Ceramic Yearbook I. 2001, ÉTK and MÉASZ, Budapest, ISBN 963512774 X pp.30-85

https://www.researchgate.net/publication/Keramiaipari_evkonyv_I_2001

[4] Jia, Shuhai (2005) Synthesis of SiC Ceramics from Coal Gangue, Materials Science Forum Vols. 486-487. pp. 378-381. https://doi.org/10.4028/www.scientific.net/MSF.486-487.378

[5] Abdelfattah, M., Kocserha, I., Géber, R., Tihtih, M., Móricz, F. (2020) Evaluating the properties and mineral phases of the expanded clay aggregates with the bentonite additive material, J. Phys.: Conf. Ser. Vol. 1527012030 https://doi.org/10.1088/1742-6596/1527/1/012030

[6] Svidró, J., Svidró, J. T., Diószegi, A. (2020): The role of purity level in foundry silica sand on its thermal properties J. Phys.: Conf. Ser. Vol. 1527 012039 https://doi.org/10.1088/1742-6596/1527/1/012039

[7] Tihtih, M., Limame, K., Ababou, Y., Sayouri, S., Ibrahim, J.F.M. (2019) Sol-gel synthesis and structural characterization of $\mathrm{Fe}$ doped barium titanate nanoceramics Építőanyag - JSBCM, Vol. 71, No. 6, 190-193. p. https://doi.org/10.14382/epitoanyag-jsbcm.2019.33

[8] Tihtih, M., Ponaryadov, A.V., Ibrahim, J.F.M., Kurovics, E., Kotova, E.L., Gömze, L.A. (2020) Effect of temperature on the structural properties of barium titanate nanopowders synthesis via sol-gel process Építőanyag JSBCM, Vol. 72, No. 5, 165-168. p. https://doi.org/10.14382/epitoanyag-jsbcm.2020.27

[9] Tihtih, M., Ibrahim, J. F. M., Kurovics, E., Abdelfattah, M. (2020) Study on the effect of Bi dopant on the structural and optical properties of $\mathrm{BaTiO}_{3}$ nanoceramics synthesized via sol-gel method, J. Phys.: Conf. Ser. Vol. 1527012043 https://doi.org/10.1088/1742-6596/1527/1/012043

[10] Ma, B., Li, Y., Yan, C., Ding, Y. (2012) Effects of synthesis temperature and raw materials composition on preparation of $\beta$-Sialon based composites from fly ash, Trans. Nonferrous Met. Soc. China Vol. 22. Issue 1. pp. 129133. https://doi.org/10.1016/S1003-6326(11)61151-5

[11] Kurovics, E., Gömze, L.A., Ibrahim, J.F.M., Gömze, L.N. (2019) Effect of composition and heat treatment on porosity and microstructures of technical ceramics made from kaolin and IG-017 additive, IOP Conf. Ser.: Mater. Sci. Eng. Vol. 613012025 https://doi.org/10.1088/1757-899X/613/1/012025

[12] Sassi, M., Ibrahim J. F. M., Simon, A. (2020) Characterization of foam glass produced from waste CRT glass and aluminium dross, J. Phys.: Conf. Ser. Vol. 1527012037 https://doi.org/10.1088/1742-6596/1527/1/012037

[13] Naimuddin Ahmen (1964) Studies on the dissociation of mullite, Thesis, University of London,

https://spiral.imperial.ac.uk/bitstream/10044/1/16253/2/Ahmed-N1964-PhD-Thesis.pdf

[14] Kurovics, E., Kotova, O.B., Ibrahim, J.F.M., Tihtih, M., Sun, S., Pala, P., Gömze, L.A. (2020) Characterization of phase transformation and thermal behavior of Sedlecky Kaolin Építőanyag - JSBCM, Vol. 72, No. 4, pp. 144-147. https://doi.org/10.14382/epitoanyag-jsbcm.2020.24

[15] Ondruška, J., Húlan, T., Sunitrová, I., Csáki, Š., Łagód, G., Struhárová, A. Trník, A. (2021) Thermophysical Properties of Kaolin-Zeolite Blends up to $1100^{\circ} \mathrm{C}$, Crystals, Vol. 11, No. 2. p. 165 https://doi.org/10.3390/cryst11020165

[16] Schneider, H., Schreuer, J., Hildmann, B. (2008) Structure and properties of mullite - A review. Journal of the European Ceramic Society, 28, pp. 329-344, http://dx.doi.org/10.1016/j.jeurceramsoc.2007.03.017

[17] Moreno, E.A.X., Scian, A.N. (2015) High Purity Mullite by Slip Casting Method from Calcined Alumina and Kaolinitic Clay, Procedia Materials Science Vol. 8, pp. 245-250 https://doi.org/10.1016/j.mspro.2015.04.070

[18] Mahnicka-Goremikina, L., Svinka, R., Svinka, V. (2018) Influence of $\mathrm{ZrO}_{2}$ and $\mathrm{WO}_{3}$ doping additives on the thermal properties of porous mullite ceramics, Ceramics International,

https://doi.org/10.1016/j.ceramint.2018.06.125

[19] Mahnicka-Goremikina, L., Svinka, R., Svinka, V., Grase, L., Goremikins, V. (2020) The formation of phases with low or negative linear thermal expansion coefficient in porous mullite ceramics Építőanyag - JSBCM, Vol. 72, No. 3, 91-98. p. https://doi.org/10.14382/epitoanyag-jsbcm.2020.15

[20] Yuan, W., Li, J., Pan, C., Deng, C., Zhu, H. (2012) Synthesis of $\mathrm{Al}_{4} \mathrm{SiC}_{4}$ powders from kaolin grog, aluminum and activated carbon as raw 
materials, Advanced Materials Research Vols. 399-401. pp. 788-791., https://doi.org/10.4028/www.scientific.net/AMR.399-401.788

[21] Lee, J.G., Cutler, I.B. (1979) Sinterable sialon powder by reaction of clay with carbon and nitrogen, American Ceramic Society Bulletin, Vol. 58. pp. 869-871.

[22] Xu, L.-H., Lian, F., Zhang, H., Bi, Y.-B., Cheng, K., Qian, Y.-B. (2004) Optimal design and preparation of beta-SiAlON multiphase materials from natural clay, Materials and Design Vol. 27 (2006) 595-600 https://doi.org/10.1016/j.matdes.2004.12.017

[23] Panda, P. K., Mariappan, L., Kannan, T. S. (2000) Carbothermal reduction of kaolinite under nitrogen atmosphere, Ceramics International, Vol. 26. Issue 5. pp. 455-461.

https://doi.org/10.1016/S0272-8842(99)00068-1

[24] Çalışkan, F., Demir, A., Tatlı, Z. (2013) Fabrication of $\mathrm{Si}_{3} \mathrm{~N}_{4}$ preforms from $\mathrm{Si}_{3} \mathrm{~N}_{4}$ produced via CRN technique, Journal of Porous Materials, Vol. 20, p. 1501, https://doi.org/10.1007/s10934-013-9736-9

[25] Tatll, Z., Demir, A., Yllmaz, R., Caliskan, F., Kurt, A. O. (2007) Effects of processing parameters on the production of $\beta$-SiAlON powder from kaolinite, Journal of the European Ceramic Society Vol. 27. pp. 743-747. https://doi.org/10.1016/j.jeurceramsoc.2006.04.062
[26] Kurovics, E., Udvardi, B., Román, K., Ibrahim, J. F. M., Gömze, L. A. (2019) Examination of the carbonization process using kaolin and sawdust. WIT Transactions on Engineering Sciences Vol. 124 p. 17 https://doi.org/10.2495/MC190021

[27] Kurovics, E., Kotova, O. B., Gömze, L. A., Shushkov, D. A., Ignatiev, G. V., Sitnikov, P. A., Ryabkov, Y. I., Vaseneva, I. N., Gömze, L. N. (2019) Preparation of particle-reinforced mullite composite ceramic materials using kaolin and IG-017 bio-origin additives. Építőanyag - JSBCM Vol. 71 No. 4 p. 114 https://doi.org/10.14382/epitoanyag-jsbcm.2019.20

[28] ASTM G 65-00 Standard Test Method for Measuring Abrasion Using the Dry Sand/Rubber Wheel Apparatus, (2000) United States

$\underline{\text { Ref.: }}$

Kurovics, Emese - Kulkov, Aleksey S. - Ibrahim, Jamal-Eldin F. M. - Kashin, A. D. - Pala, Péter - Nagy, Veronika - Kulkov, Sergei N. - Gömze, László A.: Mechanical properties of mullite reinforced ceramics composite produced from kaolin and corn starch Építőanyag - Journal of Silicate Based and Composite Materials, Vol. 73, No. 4 (2021), 149-153. p.

https://doi.org/10.14382/epitoanyag-jsbcm.2021.22

\section{$3^{\text {rd }}$ ADVANCED}
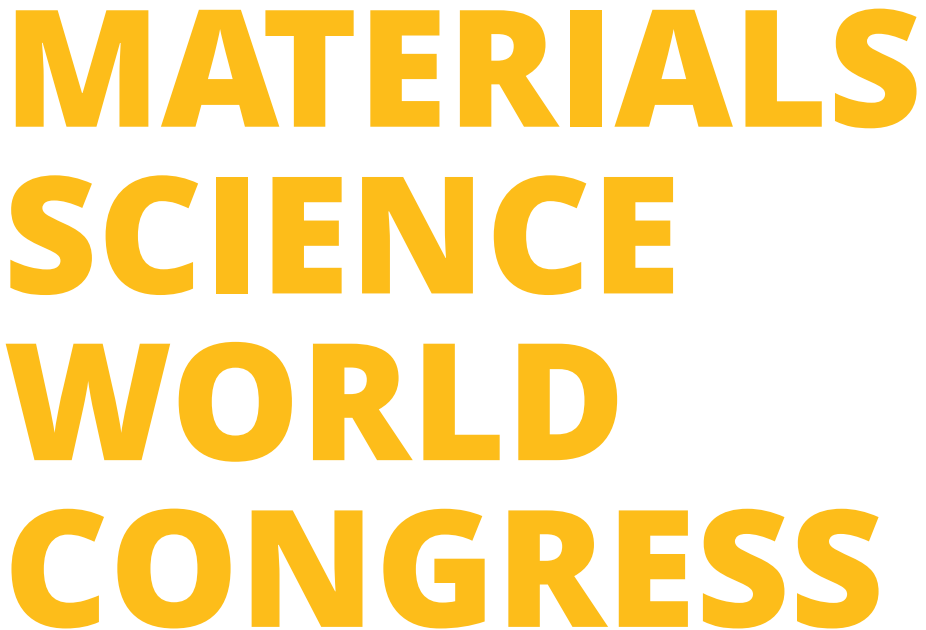

MARCH 21-22, 2022

LONDON, UK

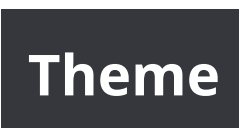

"Anticipating Future Trends, New

Insights, and Cutting-Edge Technologies in Materials Science andEngineering "

http://advanced-

materialsscience.peersalleyconferences.com/

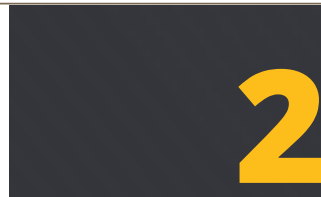

DAYS WITH MORE THAN 45 SESSIONS, KEYNOTES \& TALKS

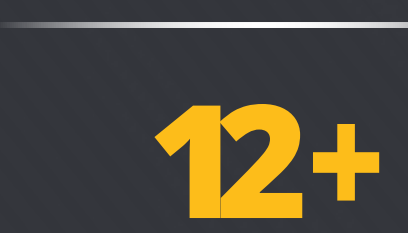

INNOVATIVE FEATURED SPEAKERS

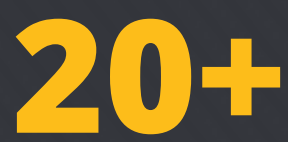

HOURS OF NETWORKING EVENTS

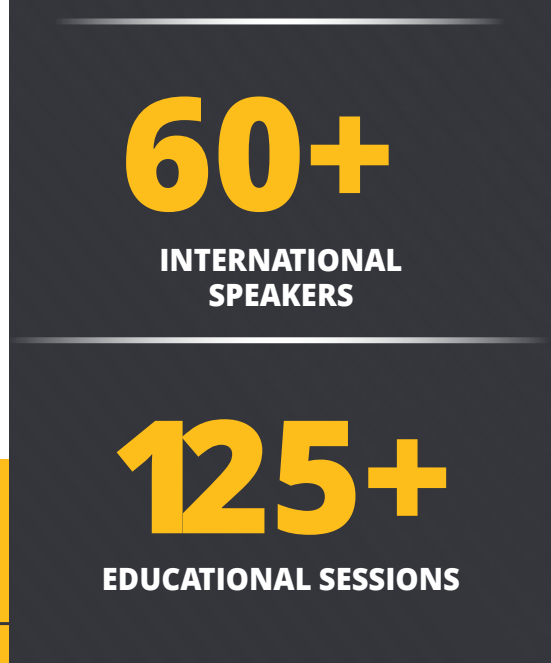

